\title{
1. Introduction: Still Loving Solidarity?
}

In the face of our societies' contemporary problems and particularly since the outbreak of the COVID-19 pandemic, it seems that everyone can agree that we need more solidarity. But this apparently simple solution is broad enough to include conflicting and competing worldviews, different imaginations, and infinite sets of social practices and political strategies. There is no consensus on what solidarity actually is-neither in public nor in academic discourses.

At the same time, something that everyone agrees on deserves our reasonable doubt. Because, like every social praxis and political demand, solidarity is never pure or innocent. Rather, different political beliefs and convictions, epistemological and cosmological perspectives, ethical and moral frameworks, as well as social structures, operate within-and not outside of-whatever we might call solidarity. In short, solidarity is as messy as any other social praxis and discourse.

Whilst the multiple crises of our societies ${ }^{1}$ today call for more solidarity, our framework of what, when, and how we perceive solidarity is complicated. Take the example of the former Sea-Watch 3 captain, Carola Rackete: in solidarity with migrants and refugees crossing the Mediterranean, she has been

I agree with contemporary diagnoses of our societies being in a state of constant and multiple crisis and precarity. Particularly, I refer to the normalised precarity under neoliberalism, especially after the financial crisis in 2007 and the subsequent political and social crisis of and in the European Union resulting from austerity politics. The contemporary political crisis is marked by a rise of neofascism across the world on the backs of multiple migration and refugee movements, themselves a consequence of the crisis of postcolonial nation-states and the effects of the climate crisis in Latin America, Africa, and Asia. At the same time, antiracist, decolonial, and feminist movements confront and resist this crisis in multiple ways. Finally, the COVID-19 pandemic lay bare the vulnerability and structural inequality of our societies and produced an ongoing state of pandemic crisis with long-lasting effects on multiple levels. 
in charge of rescuing people from boat wrecks on their way to Europe. She particularly gained worldwide attention in June 2019 by insisting on bringing 53 people to a safe harbour in Lampedusa, Italy despite contrary commands from the Italian coast guard and threats by former Italian Home Secretary and neofascist Matteo Salvini. European citizens claimed to stand in solidarity with Carola Rackete after she was detained. These declarations materialised in donations of over one and a half million euros for her and the Sea-Watch organisation after a few days. In public media, Carola Rackete became the face of European solidarity with refugees-and Europeans stood in solidarity with her.

In my undergraduate seminar in the 2019 summer term at Justus-Liebig University, entitled "Still Loving Solidarity?," we discussed this case from a decolonial and antiracist perspective. Amongst other things, we debated why Carola Rackete's agency is made so prominent compared to that of others. Why do we tell her story and not the ones of the 53 refugees in danger? Why do we need a symbol like her to stand in solidarity with refugees so that such an amount of donations would be possible? Why are her actions heroised whilst those of other refugee supporters are criminalised? What does it mean that she (and other supporters as well) can choose to engage in solidarity whilst others, particularly noncitizens, are forced to fight for their right to migrate? And finally, does asking these questions unequivocally mean a desolidarisation with her actions and the support she and Sea-Watch received? When looking out for solidarity, de-, postcolonial and antiracist perspectives thus demand us to reflect critically if we are really "all in the same boat" (Ehrmann 2019).

All these doubts point to the messiness of solidarity and how it is complicated by questions of unequal agency, privileges, vulnerability and visibility. Also, they are not limited to that particular example. Rather, they cut across all cases of external solidarity or solidarity with others-a type of solidarity in which the group who stands in solidarity is not affected by the same mechanisms of exclusion or discrimination as the group towards whom solidarity is directed. Many contemporary social justice movements-whether they are antiracist, feminist, or decolonial—struggle against these mechanisms of discrimination, oppression, persecution, violation, etc. based on their shared vulnerability. So, is there a horizon for solidarity between groups who do not share this vulnerability and, what is more, have unequal access to resources and privileges? And if there is a horizon, what does it look like in practice? What are the possibilities for solidarity for a white US-American citizen with 
the \#blacklivesmatter movement and what are its limitations? What does it mean to practice Willkommenskultur ${ }^{2}$ in Germany after 2015 and how far are we willing to take it? Are symbolic and public acts, like applauding for health care workers on our balconies during the first months of the COVID-19 pandemic, really expressions of solidarity? What is a position of solidarity for cis men in feminist struggles like \#metoo and \#niunamenos? What does it mean for white people to stand for decolonisation and what kind of actions does such a declaration demand?

Whilst the struggles for decolonisation are rather abstract and distant for people in the Global North, it is a fundamental part of the sociopolitical and cultural realities in societies of the Global South. Indigenous and Native people in particular continue to live under colonial relations within formally independent nation-states. Amongst many others, the Indigenous Mapuche in today's Chile and Argentina are key protagonists in the struggles for decolonisation in contemporary Latin America. In Chile, according to the latest national census (Instituto Nacional de Estadísticas 2017, 16), approximately $10 \%$ of the population consider themselves Mapuche, but more recent studies show that more and more people in the country begin to identify as Indigenous today (CIIR 2020, 9). Especially since the formal return of democracy in Chile after 1990s, the Mapuche's struggle for the decolonisation of their territories and society, for political autonomy and ecological justice, and against state repression and persecution has become domestically and internationally more and more prominent. At the same time, their struggle has received international support from non-Indigenous actors and organisations throughout the globe, particularly Chilean exiles and the Mapuche diaspora. Today, the social uprising in Chile beginning in October 2019 put the country again in international spotlight. ${ }^{3}$ In these social protests and the political processes leading to the election of a constitutional convention in 2021, also the demands and the situation of the Mapuche society is gaining-at least symbolically-more attention. For example, the iconic photograph of the largest demonstration of

This term that has been used particularly since 2015 to describe a refugee and migrant friendly atmosphere and welcoming culture in Germany.

3 I was finishing the first manuscript of this investigation as a PhD thesis when the protests started. While the present text therefore only engages partially with the complex and constantly changing developments in Chile since late 2019, the epilogue will try to connect the results from this research with the latest developments in the contemporary struggle for a "new Chile" led by social and indigenous movements. 
approximately two million people on October $25^{\text {th }}, 2019$, probably the largest in the country's history, has the wenufoye ${ }^{4}$, the Mapuche national flag, instead of the Chilean at its centre.

By addressing this case of international solidarity and transnational advocacy, the present study takes up the question of the limitations and possibilities of solidarity between two groups who do not share the same vulnerability. Those two groups are, on the one hand, the Indigenous Mapuche and their communities, organisations, and diaspora in Europe and, on the other, non-Indigenous, mostly white European actors and organisations who declare their solidarity or sympathy with the Mapuche and offer their support in numerous ways. But who exactly are the actors and protagonists of these solidarity efforts, who has the agency, and whose agency is (made) (in-)visible? Furthermore, are these solidarity efforts in Europe coordinated together with or independently from the Mapuche in Wallmapu? ${ }^{5}$ At the same time, it is interesting to ask what kind of solidarity and advocacy actions do these different actors take, as well as if and how they actually support the Mapuche in Wallmapu. Have these actions changed over time? If we accept the idea that struggles for decolonisation are rather abstract and distant for people in the Global North, it would be of further interest to look at how non-Mapuche actors make sense of their involvement in solidarity and advocacy. What is their relation to the Mapuche and what are their political beliefs? What is the role of colonial stereotypes in the relations between Mapuche and non-Mapuche people, and are they being confronted? Finally, if contemporary calls for solidarity are criticised as empty phrases based on a blurry understanding of solidarity everyone could possibly agree upon, then what does solidarity actually mean to the involved actors in theory and in praxis? In addition, what kind of relationships do the involved actors build amongst each other? Do these encounters in solidarity and advocacy transform these relationships?

These are some of the questions that the present research aims to discuss through a committed ethnographic approach. They inform the overall re-

This flag has been accepted and shared by most of the Mapuche organisations and communities since 1992. Instead of a nationalistic symbol, the wenufoye should rather be understood as a "symbol of ideological decolonisation" (Pairican 2019; my translation).

5 Wallmapu is the name of the ancient territory of the Mapuche in the southern parts of today's Chile and Argentina. On the Western (Chilean) side of the Andes, the territory is called Gulumapu, on the Eastern (Argentinian) side, Puelmapu. Although this research refers mostly to Gulumapu, I will continue using the term Wallmapu. 
search question about the limitations and possibilities of solidarity between these groups (Mapuche and non-Mapuche) against the backdrop of the racialised, gendered, and colonial hierarchies and differences between them. In this way, I will not discuss solidarity in abstract terms, but rather base my elaboration on its concrete social and political expressions in a particular ethnographic case study, which I undertook from 2014 to 2017 in Europe and Chile. I will later detail this methodological approach as an ethnography of and in solidarity - a research agenda about expressions and experiences of international solidarity, conducted in solidarity with the involved actors. This enables a conceptualisation and analysis of my own position in (possible or limited) solidarity as an object of study within the ethnographic process. This multi-sited, networked, and committed ethnography included my active participation in solidarity networks, which allowed me to follow actors, sites, and processes of solidarity between Europe and Chile. Another key element of this methodological approach is the idea of an ethnographic translation that puts different knowledges within a crowded field of thoughts and ideas into conversation. This methodological approach presents some difficult challenges that will further nurture my understanding of the limitations and possibilities of solidarity across and beyond differences.

Through this ethnography of and in solidarity, and with the general research question as a starting point, the study looks at different but complementary arenas of solidarity: the networked aspect of solidarity, the strategies and tactics, the role of stereotypes and privileges within solidarity action, and finally the everyday praxis and interpersonal encounters of solidarity.

These arenas will be investigated each with a corresponding underlying research question by asking: 1) Who are the protagonists of these solidarity efforts and how is their network structured and organised?; 2) What are the political strategies and tactics of these solidarity and advocacy efforts?; 3) What is the role of privileges and (colonial and racist) stereotypes within these solidarity efforts (and if they are confronted, how)?, and 4) What are the social practices and interpersonal encounters of solidarity and what are their effects? Each of these underlying research questions will be discussed in a separate chapter and will inform the closing discussion about the limitations and possibilities for solidarity in the present case.

Over time, the research focus shifted significantly and changed the overall direction of this investigation. Originally, I had assumed that solidarity and advocacy with the Mapuche in Europe is carried out foremost by nonIndigenous actors and organisations. Very much to the contrary, at the begin- 
ning of my ethnography I found myself in a scenario in which (diasporic) Mapuche actors and organisations have a significant role, and shape and transform the solidarity network, its actions, and its aims. This means that I encountered international solidarity with the Mapuche as solidarity carried out foremost by Mapuche actors themselves, subsequently supported by a wide range of different non-Mapuche actors and organisations. As a reaction to this situation, the present research discusses solidarity, on the one hand, as relations, (dis)encounters, and interpersonal experiences between Mapuche and non-Mapuche (European as well as Chilean) actors across and beyond their differences; on the other, it tries to understand solidarity as a crowded field of transnational advocacy to support the struggle of the Mapuche in Chile, in which all these actors participate with different positionalities, privileges, resources, motivations, and aims. Research questions one and two focus on the latter (chapters four and five), whilst questions three and four address the former (chapters six and seven).

Towards the conclusion, I will be able to formulate an empirically and theoretically informed notion of (international) solidarity that connects actors across and beyond differences and transforms their relationship by taking into consideration their historically and structurally heterogenous sociocultural and political experiences. Solidarity as a transformative and creative relationship is thus open and without guarantees, but has the potential to produce relationships that are based on mutuality, reciprocity, and horizontality. If these relationships are sustainably perpetuated in close interaction, they generate new and heterogenous social assemblages amongst the involved actors. In summation, I will show how (international and political) solidarity transforms and creates (new) social bonds (i.e., social solidarity).

The final analysis will hopefully not only shed light on contemporary political and social expressions of solidarity between the Mapuche and nonMapuche, but also on other cases of solidarity between unequally situated groups. Finally, this research hopes to update discussions about solidarity that have rarely focused on the inequalities involved from an antiracist and decolonial perspective. In this way, it seeks to dust off solidarity as a crucial and much needed tool for contemporary struggles for social justice in today's times of multiple and pandemic crisis. At the same time, it seeks to show how these experiences demand and point out new forms of sociability and conviviality (Gutiérrez Rodríguez 2015) across and beyond differences. 
A central aim of the present research is to update notions of solidarity based on its historical definition of describing international or domestic connections between political and sociocultural struggles (Süß and Woyke 2020). This meaning of solidarity refers to its political dimension, which creates bonds amongst actors who seek to achieve a particular goal against an antagonist (Bayertz 1998a; Scholz 2008). Such political notions of solidarity usually describe the experiences of international or domestic connections amongst and between collectives who share a certain political ideology or class position. Nevertheless, only a few studies have focused on what happens to such political solidarities if the involved actors and groups do not share the same background, vulnerability, and access to resources. This raises the question of how to deal with difference within struggles in solidarity. In fact, not only will this research aim to contribute to the discussions about the limitations and possibilities of political solidarity across and beyond differences, but it will show how the sole focus on the political dimension of solidarity falls short in understanding such experiences and (dis)encounters.

Some authors have detailed various historical expressions of the political solidarities and connections in the last centuries amongst groups and actors beyond differences - whether they are racial, colonial, or ethnic, or on the basis of a different citizenship or class belonging (Featherstone 2012; Gandhi 2006; Linebaugh and Rediker 2013). A particular focus on difference within solidarity further helps to value the agency of groups who have been silenced or forgotten as political protagonists in a common struggle-for instance, those who took part in the student uprisings in West Germany in the 1960 s (Seibert 2008; Slobodian 2012). These studies do more than just bring back such silenced and forgotten actors into the narrative of historical experiences of solidarity; they also enrich the debate by confronting us with these actors' different ways of organising and practicing solidarity, their analysis of political problems, as well as their different foci for struggles. The present case also shows how Mapuche actors themselves have been and still are the protagonists of the transnationalisation of their struggle and that they shape the international solidarity network through their ideas and concepts. The aforementioned critical historical approaches also indicate how, for example, in the second half of the twentieth century, colonised, Third World, or Indigenous people have fought parallel battles against racism and coloniality within the shared struggles in solidarity with people from the Global North or white activists. Furthermore, whilst the resistance against racism and coloniality was subsumed or even silenced under the assumed common goals of national lib- 
eration in the Global South and socialist internationalism, they became more and more visible as struggles of their own after the fall of the Berlin Wall (Seibert 2008).

By the 1990s, the quest for a socialist solidarity became increasingly sidelined and movements against racial injustice and right-wing terror, as well as decolonial and noncitizens' movements, demanded new forms of solidarity from possible allies beyond the old-fashioned forms of international solidarity. For the Global North, this meant shifting the focus from revolutionary or national liberation movements in the Global South towards their own domestic context, confronting itself and its racial and colonial continuities (Steyerl and Gutiérrez Rodríguez 2012). Thus, in the 1990s, the right-wing terror attacks in Rostock-Lichtenhagen, Hoyerswerda, Mölln, and Solingen in Germany, the assault on Rodney King and thousands of other African-Americans in the US, the racial discrimination and marginalisation in the banlieues in France, and the securitised border regimes all over the Global North began to demand more and possibly a different type of solidarity than the revolutionary movements in the distant mountain ridges of Cuba, Nicaragua, or Vietnam.

Such demands for antiracist types of solidarity pushed actors in the Global North to reflect about and reconsider their former concepts and ideas of internationalist solidarity (Foitzik and Marvakis 1997). Primarily, the post- and decolonial critiques from authors and activists with backgrounds in the Global South, who are first- or second-generation residents of the Global North, demanded a reconsideration and reflection about the possibilities and limitations of solidarity across differences. Amongst other things, they contributed to understanding how the imaginations of regions or people in the Global South are influenced by colonial representations (Said 2003) or how wellmeaning advocacy reproduces paternalism and silences subaltern voices (Alcoff 1992; Spivak 1988). Such critiques began to trouble and complicate ideas of solidarity across differences because they understood its practice as located within colonial and racial structures, not outside of them (Mohanty 2003). As such, solidarity might even reproduce these structures of colonial and racial inequalities, as long as it remains nonperformative, does not change the terms of the relationship, and does not redistribute material (access to) resources (Ahmed 2004). Based on these post- and decolonial critiques of the possibilities and limitations of solidarity, only a few studies have taken up the challenge to empirically study expressions of (international or domestic) solidarity and transnational advocacy, with a focus on the differences between the in- 
volved groups and actors (Land 2015; Mahrouse 2014). And despite the newly increasing theoretical interest in solidarity, there are only a few contemporary testimonies, which valorise the epistemic and critical potential of practices of solidarity and mutual aid that are being carried out from below and on the ground by subalternised actors, groups and organizations, for example in the context of the COVID-19 pandemic (Sitrin and Colectivo Sembrar 2020).

The present study takes up these theoretical and empirical antecedents and critically discusses whiteness, privileges, and the continuation of colonial stereotypes-exemplified in the notion of 'Maputhusiasm'-within international solidarity and advocacy. It aims to enrich these ongoing debates by ethnographically translating and discussing the perspectives on these issues of the Mapuche actors involved. The present research hereby aims to complicate notions and possibilities of solidarity by focusing on the different positionalities between the involved actors and groups-in this case, Mapuche and non-Mapuche (non-Indigenous Chileans and European citizens). In that context, difference is essentially the result of the modern and colonial intersubjective order that has foregrounded and continues to rearticulate ideas of race (Quijano 2014a). Particularly, the Indigeneity of the Mapuche can only be understood as an essentially colonial category (Bonfil Batalla 1972) that helps to explain their illegitimate citizenship (Silva Tapia 2016) in today's Chile. In that way, this study introduces another context in which solidarity is complicated by the involved actors' different positionality and vulnerability. It takes their difference as a starting point and looks at its effects on particular expressions of international solidarity and transnational advocacy.

The case of the Mapuche is further insightful because it connects historical experiences of international solidarity from the twentieth century with contemporary forms of struggle. In the second half of the twentieth century, many Latin American countries aligned themselves with other nations in the Global South, seeking a third way beyond US-dominated capitalism and USSR-dominated state communism (Young 2001). In countries like Cuba, Chile, and Nicaragua, this led to revolutionary processes and movements in favour of a domestic alternative of socialist development towards social justice and away from the US imperialist policy in the region. These developments became not only (sometimes romanticised) inspirational sources for the struggle of socialist movements and parties in the Global North, but also led to sustained waves of solidarity with their comrades in the Global South (Balsen and Rössel 1986; Georga and Arenhövel 1992). Such experiences of solidarity included declarations, protests, and information campaigns in the Global 
North, as well as monetary donations and funding for these revolutionary movements. Activists from the Global North also travelled to these countries to support alphabetisation campaigns or even the armed struggle. But these political projects and their international solidarity became marginalised on a regional level after incisive events like the electoral loss of the Sandinistas and the return to formal democracy in Chile in 1989. On a global scale, the fall of the Berlin Wall and the disintegration of the Soviet Union and its historical horizon for socialist change further frustrated such developments in Latin America and their allies in the Global North.

However, shortly after the false assumption of the end of history (Fukuyama 1992), with the Zapatistas and the EZLN in Mexico, a new revolutionary movement from Latin America surfaced and sparked international fascination, along with new waves of solidarity. It updated antiimperialist and anticapitalist language and iconography into a new form of decolonial struggle by transculturalising Western and Indigenous political ideas. This anticapitalist and antipatriarchal decolonial struggle proposed a new horizon for political change and emancipation for people around the world (Hayden 2002). In a similar way, the Mapuche in Chile and Argentina opted for strategies favouring their political, sociocultural, epistemological, and territorial autonomy without neglecting their situatedness within a Westernised framework from the 1990s onwards (Marimán 2012; Tricot 2013). But, in contrast to the Zapatistas, international solidarity with the Mapuche since the late twentieth century is framed by the experiences of international solidarity with the Chilean people after the military coup in 1973. In that way, the contemporary expressions of solidarity with and by the Mapuche are historically linked to these older experiences of international solidarity.

With this historical framework in mind, the present study is based on the idea that decolonial movements, especially of groups in Latin America, such as the Zapatistas or the Mapuche, ${ }^{6}$ serve as key reference points for contemporary expressions of international solidarity in the Global North. Nevertheless, the struggle of the Mapuche in particular is largely overlooked and internationally unrecognised. For that purpose, the present study provides a detailed

6 One could add to this the Indigenous mobilisations in Peru, Bolivia, and Ecuador that, since the 1990s, have managed to materialise political changes in their respective countries, such as the legal frameworks surrounding the Aymara and Quechua ideas of Sumak Kawsay/Sumaq Qamaña in the constitutions of Bolivia and Ecuador or the proposals of the "Living Forest" led by Amazonian women (Sempértegui 2020). 
account of how the struggle of the Mapuche became transnationalised since the 1970s (chapter four) and explains the reasons for transnational Mapuche advocacy transcending the domestic context in Chile, as well as its framework and strategies (chapter five).

Notwithstanding, using Indigenous movements as reference points for struggles for liberation and emancipation is not without its difficulties. On the one hand, such decolonial movements outside of Eurocentric constraints are often conceptualised as historical alternatives outside of the left-wing melancholia (Traverso 2017) in the Global North-that is, a state of mind to mourn and self-reflect upon the failed and defeated left-wing political projects throughout the twentieth century, that nevertheless continue to inspire future political action. As such, they carry the burden of representing a historical horizon for humankind beyond late capitalism and the climate crisis. Put in drastic terms, the Global North needs to "forget the socialist mumbo-jumbo and play the Indian card" (Oppenheimer 2002, 54). The present research will engage in that debate and discuss the complicated relationship between the Mapuche and the non-Indigenous Left, as well as the consequences and opportunities arising thereof.

On the other hand, and taking the insights from postcolonial critique to the context of the Americas, there is a long-lasting tradition in the Global North of stereotyping and romanticising American Indigenous and Native people (Berkhofer 1979). Particularly, the German-speaking context has been analysed as overly enthusiastically engaging with and referring to Indigenous people and Native Americans. Here, the term "Indianthusiasm" intends to describe the particular German racial gaze through which Indigenous people and Native Americans are racially stereotyped, idealised, and romanticised (Calloway, Gemunden, and Zantop 2002; Usbeck 2015). In addition to these debates, the present study seeks to critically discuss the relevance of a Maputhusiasm within the expressions and experiences of international solidarity and advocacy with and of the Mapuche.

Before discussing each topic in a separate chapter, this research will present its theoretical and methodological foundations. The theoretical focus of this study is the concept and idea of solidarity, which will be tackled from different disciplinary backgrounds in the humanities, as well as social and cultural sciences. After offering a brief history of the concept of solidarity, this chapter will provide four conceptual distinctions of solidarity that are widely accepted in academic literature today: solidarity as a universal ethical norm, solidarity as a concept to describe mechanisms of creating social bonds, 
solidarity as a mutual civic responsibility within modern nation-states, and finally solidarity as a concept for political struggle. These approaches to solidarity have sometimes led to disagreements around a series of controversies and provide contemporary diagnoses that will be presented in the following section. Nevertheless, in these historical and conceptual approaches, as well as in contemporary debates and controversies, the understanding of solidarity is limited, since it does not take into consideration gendered, colonial, or racialised differences or critically address social and political hierarchies.

This is why, after these hegemonic debates, the chapter will move on to discuss critical approaches to solidarity. It begins by discussing if and how solidarity is a concept that helps to understand the transformation and production of new sociopolitical relations, before turning the focus on the question of difference in solidarity. This section will present theoretical insights that inform a potential decolonisation of the Western idea of solidarity. I will particularly focus on discussions about the limitations and possibilities of solidarity across and beyond differences from critical race, decolonial, and feminist approaches. These critical perspectives will finally allow to formulate a notion of solidarity as a conflictive relationship between actors with different positionalities, privileges, resources, and motivations. This critical approach thus shifts the focus to questions of agency and difference in solidarity, as well as its potential for critical decolonised social relations.

The last two sections of this chapter have a similar approach: First, I provide a brief overview of the more prominent and hegemonic theoretical approaches of new social movement research, particularly the transnationalisation of Indigenous resistances. Afterwards, I will articulate some challenges and critiques of Eurocentrism within this theoretical field. This will allow to develop a theoretical approach of the transnationalisation of the Mapuche struggle that recognises the heterogeneity and differences of the involved actors, goes beyond the nation-state container, and considers its networked structure as a decentralised rhizomatic field that produces connectivities and relationalities as new assemblages.

Chapter three describes the research process as a networked, activist ethnography of and in solidarity from 2014-2017 in Chile and Europe. The epistemological point of departure draws inspiration from Marxist and (Black) feminist epistemology, which will guide the following inquiry and research questions. The research methodology is stimulated by research programmes such as Participatory Action Research, ethnography, and decolonial methodologies. Combining these programmes led to the set of research 
methods that were used to answer the research questions. The reader will be able to follow the steps of my networked activist ethnography, which started in 2014 in Europe and led me to conduct fieldwork in Europe over a period of three years and to undertake two research trips to Chile in 2016 and 2017. In this section, I will introduce the key interlocutors and sites of my research and propose some reflections about the research process, questions of how to balance academic and activist spaces, how to deal with (my own and others') vulnerability, and how to make academic results beneficial for those who participated in my research.

The first chapter introduces the networked features of international solidarity based on the transnational cultural politics of autonomy of the Mapuche. It hereby presents the main actors of the solidarity network with and of the Mapuche and introduces some features of this network's structure. I will argue that international solidarity with the Mapuche is based on a culturally embedded understanding of the Mapuche's autonomy. For that purpose, this chapter begins with an exploration of their cultural politics of autonomy starting from historical experiences of political autonomy until today's mobilisations and conceptualisations. The contemporary solidarity network's structure needs to be understood as a result of the diasporic experience of the Mapuche after the military coup in Chile in 1973 and the subsequent transnationalisation of Wallmapu as a site of resistance and hope. This is because the first- and second-generation diaspora of the Mapuche are today's main protagonists of the solidarity network. Finally, I will propose to understand this network's structure and organisation as an expression of autonomous cultural politics based on five characteristics: it is essentially decentral and rhizomatic; solidarity is pursued as a form of international relations with non-Mapuche actors and organisations; solidarity is a form of struggle that is hidden and obscured to non-Mapuche outsiders; solidarity is woven by the agency of the Mapuche themselves; and solidarity takes place within different arenas of political and sociocultural life.

The second empirical chapter looks at the political strategies and tactics of transnational Mapuche advocacy (TMA) employed by Mapuche representatives, communities, and organisations from Wallmapu, the Mapuche diaspora, as well as non-Mapuche actors and organisations. I propose to understand these strategies and tactics as expressions of transnational advocacy seeking to overcome the domestic blockage of the Mapuche's political and sociocultural articulation in Chile. In that context, particular as well as structural issues are made internationally prominent and are articulated within a 
master and several injustice frames for transnational advocacy. The first key strategy of Mapuche and non-Mapuche allies involves their informational politics via producing and pluralising information, as well as by raising awareness and sensitivity about the situation in Wallmapu. I will put a special focus on contemporary digital Mapuche media and digital Mapuche activism, as well as the challenges and transformation this activism faces today. Second, transnational advocacy produces political pressure through a series of symbolic politics and protests that seek to create leverage and accountability amongst powerful domestic or international actors. As a third step, I will present two case studies of how international solidarity aims to fortify Mapuche communities and organisations through financial support and funding. I will engage with critiques and alternatives that Mapuche actors articulate regarding these experiences. The chapter closes with a section on how transnational advocacy becomes 'Mapuchised' through transcultural dialogues and translations as a political strategy employed by Mapuche actors.

Chapter six critically discusses the role of privileges and (colonial and racist) stereotypes, expressed in the notions of whiteness and Maputhusiasm, within experiences of solidarity. The chapter starts by looking at how non-Mapuche supporters establish contact and make connections with the struggle of the Mapuche, and how this reflects their privileges. Based on interviews with these actors, I discuss their ideological and political references to the Mapuche resistance. These statements will demonstrate the complicated relationship between the Mapuche and (Western, Eurocentric, and nonIndigenous) Leftism, and how solidarity might become dangerously depoliticised but also eventually lead to an ecological cosmopolitanism from below. The final section of this chapter discusses the notion of Maputhusiasm as a representational framework activated by non-Mapuche, particularly German, actors that racialises and stereotypes the Mapuche culture and society through mostly positively connoted, romanticised, and antimodern imaginaries. Their awareness of these stereotypes ultimately results in a quest for an authentic experience with the Mapuche within solidarity and advocacy activism. Finally, I will enter into a critical conversation with some of my Mapuche interlocutors about these stereotypes and their different strategies of confronting and transforming them.

The last empirical chapter will discuss the critical practices and interpersonal encounters and assemblages of solidarity through three principles: solidarity as a critical commitment (compromiso), as critical practices of sharing (compartir), and finally as a communal, mutual responsibility and the creation 
of social bonds (keyuwvn and mingako). Looking at the interpersonal practices of solidarity enables a critique of white agency and paternalism within experiences of solidarity. In contrast, compromiso relates to more ethical practices of solidarity. In the present case, solidarity is also articulated and performed as a practice of sharing time-compartir-and exchanging spaces, goods, and knowledge. These practices might lead to exploitative relations within solidarity action, in which non-Mapuche actors might extract a surplus. The Mapuche propose a series of mechanisms through which possible exploitative relationships are evaded and relations of solidarity become beneficial through mutual redistribution. Finally, these interpersonal practices of solidarity between Mapuche and non-Mapuche assemble new forms of social encounters, based on a Mapuche understanding of solidarity as a communal, reciprocal, and horizontal relation-solidarity as keyuwvn or mingako. Such relations of solidarity are sought to be enduring and socially intimate. On that basis, relations of political solidarity between Mapuche and non-Mapuche can be transformed and assembled into relations of mutual identification, recognition, belonging, mimesis, or family and friendships ties.

Before entering the maze of solidarity with the Mapuche, this introduction requires some formal remarks. The quotations from my ethnographic interviews with most of the interlocutors are anonymised. Some interview partners are referenced with their full names, either because they have a public role as political or cultural representatives or because of their renowned contribution to international solidarity efforts. The final pages provide an appendix with glossaries of the most recurrent abbreviations and for the words used in Mapuzugun, as well as a list of the interviews referenced in this work. As indications of location and language, Wallmapu and Mapuzugun will remain capitalised. All other terms in languages different than English, amongst them Mapuzugun, will be written according to their own capitalisation rules and in italics. As far as possible, the terms in Mapuzugun will be written according to the Mapuche alphabet proposed by Raguileo Lincopil (Berreta, Cañumil, and Cañumil 2008). 
